Universidad de Lima

Facultad de Derecho

Carrera de Derecho

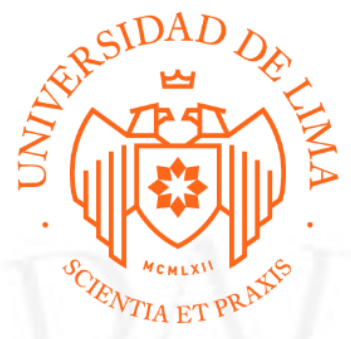

\title{
CIVIL: "EJECUCIÓN DE GARANTÍAS" Y ADMINISTRATIVO: "PROCEDIMIENTO ADMINISTRATIVO SANCIONADOR"
}

Trabajo de suficiencia profesional para optar el Título Profesional de Abogado

\author{
Javier Ayrton Lapa Carhuas
}

Código 20100630

$$
\text { Lima - Perú }
$$

Septiembre de 2019 


\section{CIVIL: "EJECUCIÓN DE GARANTÍAS" \\ Materia: Ejecución de Garantías \\ $\mathrm{N}^{\mathrm{o}}$ de Expediente: 80518-2004-0-0100-J-CI-50 \\ RESUMEN}

El problema jurídico que aborda el expediente se centra en el artículo $172^{\circ}$ de la Ley $\mathrm{N}^{\circ}$ 26702, Ley General del Sistema Financiero y del Sistema de Seguros y Orgánica de la Superintendencia de Banca y Seguros, que fue modificado por el artículo $1^{\circ}$ de la Ley $\mathrm{N}^{\circ}$ 27682 que entró en vigencia el 10 de marzo de 2002 y a la vez dicha modificación fue derogada el 22 de octubre del mismo año; período dentro del cual se celebró la escritura pública de constitución de garantía hipotecaria que es utilizada al interior del proceso.

Así, se analiza si la norma bajo comentario permitía determinar una serie de futuras operaciones de crédito que podían ser garantizadas con la hipoteca, o si a razón contraria, para la constitución válida de una garantía hipotecaria a favor de una empresa del sistema financiero se tenía que determinar en forma absoluta las obligaciones garantizadas, no siendo suficiente que se consignen obligaciones mencionadas en forma genérica que pueden ser susceptibles de ser determinadas posteriormente. 
ADMINISTRATIVO: "PROCEDIMIENTO ADMINISTRATIVO SANCIONADOR"

Materia: Procedimiento Administrativo Sancionador

$\mathrm{N}^{\circ}$ de Expediente: 00066-2012-GG-GFS/PAS

\section{RESUMEN}

El conflicto de intereses que aborda el expediente administrativo pasa por analizar sí se cometieron o no sendas afectaciones a los principios y garantías del derecho administrativo, en particular, el derecho al debido procedimiento administrativo en su vinculación con el derecho de defensa, el principio de tipicidad y el principio de razonabilidad. Procedimiento administrativo sancionador iniciado por el Organismo Supervisor de la Inversión Privada en Telecomunicaciones en contra de A. M. P. S.A.C. 